HID 48 (2021)

\title{
"QUE A CABSA DE NO ENTENDER LA LENGUA NO SABEN NI ENTIENDEN COSA ALGUNA". ACTITUDES Y CONFLICTO LINGÜÍSTICO EN MORISCOS Y CRISTIANOS VIEJOS EN LA CASTILLA DEL SIGLO XVI ${ }^{1}$
}

\author{
"QUE A CABSA DE NO ENTENDER LA LENGUA NO SABEN \\ NI ENTIENDEN COSA ALGUNA”. ATTITUDES AND LINGUISTIC \\ CONFLICT AMONG MOORISH AND CHRISTIANS \\ IN $16^{\text {TH }}$ CENTURY CASTILE
}

\author{
Mercedes Abad Merino \& Juan Francisco JimÉnez Alcázar \\ Universidad de Murcia \\ mabad@um.es ORCID: https://orcid.org/0000-0002-7664-3470 \\ jimenezalcazar@um.es ORCID: https://orcid.org/0000-0002-0934-2774
}

RESUMEN: En la frontera del reino de Granada se generó una situación lingǘstica conflictiva que vamos a estudiar desde la perspectiva de los hablantes. Analizaremos cuál era la actitud lingüística de cristianos viejos y moriscos frente a la lengua del otro; cómo se muestran juicios y valoraciones sobre ella, o cómo se llegan a extender más allá de los rasgos puramente lingüísticos hasta otras esferas culturales y sociales. Emplearemos principalmente fuentes documentales inéditas, que nos aproximen a esta particular situación histórico-lingüística y que nos permitan obtener información directa sobre la discriminación que ocasiona la diferencia lingüística. Analizaremos el discurso lingüístico, mostrando testimonios que se refieran explícitamente a la lengua de diversas formas.

PALABRAS ClAVE: Reino de Granada; moriscos; actitudes lingüísticas; conflicto lingüístico; siglo XVI.

ABSTRACT: On the border of the kingdom of Granada, a conflictive linguistic situation was generated which we will study from the perspective of the speakers.

Recibido: 22-9-2020; Aceptado: 18-12-2020; Versión definitiva: 20-12-2020

1. Este trabajo se encuadra entre los resultados del Proyecto de investigación del Programa Estatal de Generación del Conocimiento y Fortalecimiento Científico y Tecnológico del Sistema I+D: $L a$ construcción de una cultura fiscal en Castilla: poderes, negociación y articulación social (ca. 12501550) (PGC 2018-097738B-100), integrado en la red Arca Comunis.

Copyright: (C) Editorial Universidad de Sevilla. Este es un artículo de acceso abierto distribuido bajo los términos de la licencia de uso y distribución Creative Commons Reconocimiento-NoComercialSinObraDerivada 4.0 (CC BY-NC-ND 4.0) 
We will analyze what was the linguistic attitude of old Christians and new convert Moorish towards the language of the other; how judgments and evaluations about it are shown, or how they come to extend beyond purely linguistic features to other cultural and social spheres. We will mainly use unpublished documentary sources that bring us closer to this particular historical-linguistic situation and that allow us to obtain direct information about the discrimination caused by linguistic difference. We will analyze the linguistic discourse, showing testimonies that explicitly refer to language in different ways.

KEYWORDS: Kingdom of Granada; moorish; linguistic attitudes; linguistic conflict; $16^{\text {th }}$ century.

\section{INTRODUCCIÓN}

La frontera entre los reinos de Castilla, cristiano, y el de Granada, musulmán, no solo fijaba los límites geográficos, sino que marcaba el umbral entre dos universos culturales complejos y opuestos, caracterizados por usos y costumbres completamente diferentes, entre los que hay que destacar el empleo de una lengua distinta a cada lado de esa frontera. Después, cuando las tierras granadinas fueron incorporadas a la Corona castellana, esas diferencias subsistieron, pues una forma de vida no puede cambiarse instantáneamente por decreto, ni una lengua tampoco, lo que creó desconfianza y recelo por ambas partes, ya que el concepto de "vencedor" y "vencido", además de la propia esencia de alteridad entre ambos grupos, se mantuvo después de la Conversión General.

En un panorama tan complicado como este, la lengua ocupó un lugar muy destacado, ni mucho menos secundario, que impregnó a otros muchos planos como el político, el social o incluso el económico de este momento histórico. De ahí que las referencias a las diferencias lingüísticas se encuentren en tratados, crónicas, discursos, leyes, o que se conviertan en un elemento más de las comedias auriseculares más exitosas. La lengua, sin duda, llega a convertirse en una seña de identidad acusada, aunque este es un concepto muy problemático y especialmente complejo en la situación sociolingüística que analizamos².

Es una perspectiva complementaria a la estrictamente social, abordada en múltiples trabajos ${ }^{3}$, que ayuda a comprender el contexto en el que se desarrolló el que podemos calificar de conflicto manifiesto. En esta ocasión queremos destacar especialmente la situación lingüística compleja en la que se vivía, pero vista desde la óptica del hablante. Es decir, nuestro objetivo es aproximarnos a la conciencia lingüística en la medida de lo posible, para analizar cuál era la actitud lingüística de cristianos viejos y moriscos frente a la lengua del otro ${ }^{4}$; cómo se

2. Abad Merino 2017b.

3. Sirva como ejemplo la reciente compilación de estudios coordinada por Jiménez Estrella y Castillo Fernández (2020) sobre la rebelión morisca de 1568.

4. Podría decirse que se trata de una situación de lenguas en contacto no en el sentido estricto que Weinreich (1974, p. 17) estableciera: "se dirá que dos lenguas están en contacto si son usadas 
muestran juicios y valoraciones sobre ella, o cómo se llegan a extender más allá de los rasgos puramente lingüísticos hasta otras esferas culturales y sociales. Para ello nos proponemos abordar principalmente fuentes documentales inéditas, que nos aproximen a esta particular situación histórico-lingüística y que nos permitan obtener información directa sobre las actitudes lingüísticas, la discriminación que ocasiona la diferencia lingüística, o cómo se amplían esos juicios lingüísticos a las costumbres en general, con la creación de estereotipos. Analizaremos el discurso lingüístico, y mostraremos testimonios que, referidos explícitamente a la lengua de cualquier modo, tanto porque hablen sobre las diferencias como porque muestren distintas formas de reproducir la lengua del morisco en cualquiera de sus planos, para llegar, finalmente, al estudio de las valoraciones.

Consideramos que no procede realizar un repaso histórico del devenir del periodo fronterizo, de la etapa mudéjar en el reino granadino y de la posterior morisca tras la Conversión General de 1501, habida cuenta de que son procesos conocidos y que no aportan más información que la imprescindible para una adecuada cronología que enmarque nuestro estudio ${ }^{5}$.

\section{MUDÉJARES Y MORISCOS: CONCIENCIA Y ACTITUDES LINGÜÍSTICAS}

A través de los distintos testimonios localizados en las fuentes documentales podremos analizar actitudes hacia la totalidad del grupo, hacia su lengua y, finalmente, hacia los hablantes de esa lengua, ya que en muchas ocasiones la valoración se dirige a los moriscos en su totalidad como grupo, pero otras veces se refiere solamente a la lengua, como tendremos ocasión de comprobar.

Aunque esta faceta de la lengua se ha abordado mayoritariamente desde el plano sincrónico, nuestra perspectiva de análisis es la diacrónica. Algunos trabajos sobre actitudes lingüísticas se centran exclusivamente en las actitudes hacia la lengua misma; sin embargo, en opinión de Fasold ${ }^{6}$, la definición de actitud

alternativamente por las mismas personas. Los individuos que usan las lenguas son, por lo tanto, el punto de contacto", sino en el más amplio que se refiere a que el contacto se da entre los individuos que las hablan; es decir, que se puede hablar de contacto de lenguas cuando en una situación cualquiera dos códigos lingüísticos establecen un contacto (Moreno Fernández 1998, p. 257). No se trata de bilingüismo lingüístico en el sentido clásico del término, entendido como "la costumbre de usar alternativamente dos lenguas" (Weinreich 1974, p. 17), sino que hemos de considerarlo como uno de los tipos de bilingüismo social que diferencian Appel y Muysken (1996, p. 10), concretamente como esa situación en la que cada lengua es hablada por un grupo diferente en una misma comunidad y la comunicación se logra por medio de algunos individuos bilingües. Las otras situaciones son: que todos o casi todos los hablantes de la comunidad sean bilingües; o la coexistencia de un grupo monolingüe y uno bilingüe, este último a menudo dominado o minoritario.

5. No obstante, y como referentes básicos, podemos recurrir a los diversos estudios de A. Domínguez Ortiz, M.Á. Ladero Quesada, J.E. López de Coca Castañer, B. Vincent, M. García-Arenal, R.G. Peinado Santaella, E. Soria Mesa, Á. Galán Sánchez, J. Rodríguez Molina, M. Barrios Aguilera, R. Benítez Sánchez-Blanco, A. García Pedraza, J. Castillo Fernández... y tantos otros que dedicaron y dedican su vida investigadora a este complejo tema.

6. Fasold 1996, p. 231. 
puede extenderse para abarcar las actitudes hacia los hablantes de una lengua, y una ampliación aún mayor de esa definición hace posible que se incorporen también todos los tipos de conducta relacionados con la lengua, con la inclusión de las actitudes sobre la conservación de la lengua y los proyectos de planificación lingüística.

Las categorías de análisis que distinguió Weinreich ${ }^{7}$ en una situación de lenguas en contacto están presentes, aunque en relación inversa, entre los moriscos hablantes de árabe y los cristianos hablantes de castellano, pues cada uno de los grupos manifiesta su lealtad ante su propia lengua, su orgullo como hablantes y la fidelidad a lengua materna. Comparten, además, la necesidad que tienen de ella en la intercomunicación cotidiana, así como el sentimiento de rechazo que experimentan hacia la lengua "del otro".

Como señala Moreno Fernández $z^{8}$ " "la actitud lingüística es una manifestación de la actitud social de los individuos, distinguida por centrarse y referirse específicamente tanto a la lengua como al uso que de ella se hace en sociedad", y esas manifestaciones pueden ser positivas o negativas. Esas actitudes de los otros miembros de la sociedad hacia la lengua de un grupo se proyectan también sobre los modelos culturales más característicos de ese grupo, y terminan convirtiéndose en actitudes hacia los hablantes individuales ${ }^{9}$. Es decir, esos supuestos atributos sociales de un grupo se transfieren a los rasgos lingüísticos con los que son $\operatorname{asociados}^{10}$.

López Morales ${ }^{11}$ introdujo un valioso matiz en la consideración de las actitudes que nos ofrece muchas posibilidades desde el punto de vista del análisis documental, pues separa del concepto de actitud el de creencia. Desde esta óptica, las creencias son las que producen las distintas actitudes, que pueden ser positivas, de aceptación, o negativas, de rechazo. En ocasiones, pueden basarse en la realidad, pero también pueden no estar motivadas empíricamente.

Las creencias, de antemano, tienen carácter cognitivo y, por lo tanto, carecen de contenido afectivo en sí mismas, aunque pueden desencadenar y ser desencadenadas por fuertes reacciones afectivas, y es difícil que el componente cognitivo evoque juicios carentes de contenido afectivo ${ }^{12}$. No es fácil distinguir las actitudes hacia las variedades lingüísticas de las actitudes hacia los grupos y los miembros de la comunidad que las utilizan, pues las variedades lingüísticas y sus formas

7. Weinreich (1974), apud Blas Arroyo (2005, p. 352) distingue: a) La lealtad lingüística, entendida como un estado mental que conduce al hablante a valorar de manera muy elevada su lengua y a defenderla en los procesos de sustitución. b) La fidelidad, que refleja la resistencia ante los cambios lingüísticos. c) El orgullo, o sentimiento de satisfacción personal por poseer una lengua propia. d) El prestigio, es decir, el valor que se le asigna a las lenguas para el progreso social y material. e) La utilidad, definida como el grado de necesidad de las lenguas para la comunicación ordinaria. f) El rechazo o sentimiento negativo frente a una lengua.

8. Moreno Fernández 1998, p. 178.

9. Appel y Muysken 1996, p. 30.

10. Preston 2003.

11. López Morales 1989, pp. 234-236.

12. Garrett 2010, p. 31. 
no suelen ser simplemente características de un grupo social, sino que incluso consagran lo que es distinto en su seno y en cierto sentido constituyen esa comunidad $^{13}$. No podemos obviar, por lo tanto, estos aspectos para el objeto de análisis del presente estudio por el sustrato que fue tanto la relación entre el propio núcleo morisco como por sus implicaciones con el cristiano viejo.

Las actitudes lingüísticas, pues, "se instalan en el mundo cognitivo de los hablantes, constituyendo un conjunto de creencias compartidas por sus respectivas agrupaciones sociales"14, lo que nos anuncia que las actitudes no son individuales, sino colectivas y sociales.

En el contexto del cristiano viejo y del morisco, heredero del generado entre mudéjares y cristianos tras las capitulaciones sucesivas que se hicieron durante la guerra de Granada, es donde situamos este análisis, tal y como hemos señalado desde el comienzo del estudio. Por lo tanto, es objetivo principal abordar las manifestaciones de esas actitudes lingüísticas, desde una perspectiva diacrónica, a partir del análisis de los testimonios documentales, sin olvidar lo que supuso para la evolución de los grupos sociales, con la puntualización de que los grandes grupos definidos no contaban con más configuración interna que esta identidad cultural. La fuente básica es la de una documentación excepcional, pero muy dispersa, entre diferentes fondos archivísticos, desde los locales de la antigua demarcación fronteriza hasta los territoriales de diferentes secciones de Simancas. Es una ventaja a la vez que un inconveniente, ya que no contamos con la posibilidad de acceder directamente al hablante mediante cuestionarios, ni dirigir el foco de atención hacia los aspectos que más nos podrían interesar mediante encuestas directas o guiadas; a cambio, contamos con valiosos testimonios explícitos que tan solo se han visto influidos por el momento histórico y la situación político-social de la época, lo que los convierte en idóneos para nuestro propósito, pues, tras la Conversión general, la lengua árabe fue uno de los rasgos perseguidos con más contundencia por las instituciones políticas, pero también uno de los más censurados por prácticamente todos los grupos que configuran la compleja sociedad de estos siglos. Las diferencias lingüísticas se interpretarán como diferencias religiosas, e incluso políticas, y disparidad de voluntades ${ }^{15}$, pero lo más destacable es, precisamente, que los hablantes son muy conscientes de esa diferencia, de la que se hacían eco desde todos los puntos de vista posibles. Los testimonios que han llegado hasta nosotros mediante los cuales podemos acceder a esas actitudes, positivas (las menos) o negativas, son muy elocuentes, como podremos observar en los ejemplos.

No estamos ante la obra de gramáticos, sino que se trata de testimonios de hablantes despojados de conocimientos especializados, particularmente valiosos por esa misma razón, ya que este aspecto ${ }^{16}$ nos permitirá aproximarnos a la valoración lingüística de un hablante común, entendiendo como tal "la expresión calificativa

13. Ibid, p. 16 .

14. Moreno Fernández 2012, p. 226.

15. Abad Merino 2017b.

16. Este es un aspecto esencial en la llamada lingüistica popular de Preston $(1993,1999)$. 
aplicada de modo global a una lengua o, de modo especifico, a una variedad o a un fenómeno lingüístico particular de cualquier tipo en cualquier rango del sistema"17, y más concretamente a las actitudes que hay tras su discurso.

Por otra parte, tan importante será la percepción física de la realidad lingüística como el procesamiento intelectual que elaboran los hablantes a partir de esa sensación ${ }^{18}$, pero en el análisis de un texto escrito cobrarán un protagonismo más destacado aquellos aspectos que por su naturaleza explícita nos permitan el acceso al plano más subjetivo e implícito.

La importancia que cobra el aspecto lingüístico en el seno de la sociedad de la época nos permite que podamos hablar de una conciencia reforzada. Nos da lugar a una situación privilegiada para el análisis de testimonios de los más diversos orígenes y desde múltiples orientaciones, hecho que nos aproximará a las creencias y explicaciones del hablante común sobre la variedad lingüística, que son las que apoyan sus respuestas actitudinales, para conocer de esta forma las distintas actitudes de los hablantes integrantes de estas comunidades, así como la conciencia lingüística de estas dos comunidades enfrentadas.

Hemos recopilado una serie de muestras, repartidas por distintos tipos de documentos, que recogen las ideas más extendidas en la época sobre la lengua de los moriscos, los tópicos y los prejuicios. Hemos de distinguir dos clases diferentes de testimonios en función del tipo de emisor pues, por una parte, están los escritores y autores de comedias, a los que podríamos considerar como especialistas que trabajan con la lengua y, por otro, los hablantes comunes, que no tienen una formación lingüística especial. Unos y otros, en cualquier caso, transmiten la voz de su época y las ideas lingüísticas de su grupo social, ya que, como mencionábamos antes, las actitudes se aprenden y llegan a formar parte del conocimiento compartido ${ }^{19}$. Es un fenómeno individual, pero los individuos pueden tomarse como representantes de la sociedad en la que se incluyen.

\section{LA CONCIENCIA DE LA DIFERENCIA. DiSCRIMINACIÓN LINGÜÍSTICA}

En los primeros años tras la conquista de Granada, la comunidad mudéjar, morisca después de la conversión, desconocía mayoritariamente el castellano, lo que dará lugar a una situación difícil para este grupo que, repentinamente, se vio incorporado a unos sistemas político-administrativos ajenos a ellos, y cuyos gestores ignoraban conscientemente los perjuicios que se creaban a raíz de ese desconocimiento. Podemos conocer con todo detalle esta situación asimétrica a partir del testimonio que nos ofrecen algunas cartas reales en las que se reproduce la situación.

17. Caravedo 2013, p. 46.

18. Moreno Fernández 2015, p. 217.

19. Ribas 2005, p. 120; Garrett 2010, p. 16. 
En 1495, unos años antes de la Conversión general, los mudéjares de VélezMálaga pidieron un procurador a los reyes con este fin, tal y como se recoge en la carta:

Sepades que por parte de los moros de la tierra desa dicha çibdad nos fue fecha relación, etc., diziendo que a cabsa que ellos no saben fablar sy no en algaravia e porque non entienden bien las cosas no pueden procurarles, se les siguen muchos dannos e se les recreçen muchas costas. E que por cabsadello e por no lo saber procurar por las cabsas susodichas, se les pierden sus pleitos e quedan defensos. E por nuestra parte nos fue suplicado e pedydo por merçed que vna persona que fuese avile e suficiente, syendo nonbrado por ellos, fuese costrenyda a que les ayudase e procurase por ellos e por sus cabsas e pleitos pagandole su justo e devuido salario $(\ldots)^{20}$

Más tarde, en 1503, cuando los mudéjares ya se han convertido en moriscos ${ }^{21}$, la situación no parece haber cambiado, a tenor de lo recogido en carta de la reina al corregidor de Granada, en ese momento Alonso Enríquez, en la que se informaba de la injusta situación en la que se encontraban los regidores moriscos de Granada, porque los asuntos de la gobernación se despachaban en castellano y ellos no lo hablaban, con lo que no podían participar ni hacerse entender:

Que a cabsa de no entender la lengua no saben ni entienden cosa alguna de lo que se habla e prouee en el dicho regimiento. E que por esta cabsa no dan paresçer ni voto en los cabildos e ayuntamientos. E sy le dan, tan poco se entiende lo que dizen es si algo les paresçe que se deue proueer no tienen ynterpetre que lo diga, lo qual es cabsa quellos no pueden vsar de sus ofiçios commo deuen ni dar dellos la cuenta que deuen. E me suplicaron e pidieron por merçed sobrello mandase prouer mandandoles dar vn ynterpetre, persona fiable que supiese la vna lengua e la otra, que estuviese en los dichos cabildos e ayuntamientos e les dixese las cosas que se platycasen e fordenasen en ellos para que ellos diesen su voto e paresçer o que sobre ello proueyse (sic) commo la mi merçed fuese ${ }^{22}$.

Algo similar se muestra en una carta de los reyes al corregidor de Guadix, en 1504, en la que se mandaba, según reza el encabezamiento del texto: Que admitan a los christianos nuevos convertidos que no sopieren fablar lengua castellana, a que respondan en sus pleitos por procuradores ellos e sus mugeres.

Esta situación se complica todavía más cuando se comprueba los problemas que traía consigo una competencia lingüística deficiente a la hora de cobrar las rentas, aspecto este que, con toda probabilidad, preocuparía más a las instituciones que el problema lingüístico, pero que iban de la mano:

20. Archivo General de Simancas (en adelante AGS). Registro General del Sello. 1495, abril, fol. 219 .

21. Sobre el particular, véase Villanueva Zubizarreta 2019.

22. AGS. Registro General del Sello. 1503, febrero, fol. 39. 
Sepades que por parte de los christianos nuevamente convertidos a nuestra santa fe catolica, vesinos e moradores de la dicha çibdad e su tierra, nos fue hecha relación disiendo que los arrendadores e recabdadores e arrendadores menores de las rentas de las alcaualas desa dicha çibdad e su tierra [de Guadix], los çitan e enplaçan muchas veses a ellos e a sus mugeres e fijos sobre lo tocante a las dichas rentas, e les piden e demandan muchas penas e achaques, e no consyenten ni dan logar a que respondan ni aleguen de su derecho por propio que segund el tenor e forma de las leyes de nuestro quaderno de alcaualas lo han de responder ellos mysmos por sy. E que commo son ynorantes e no saben fablar la lengua castellana, ni están ynformados de las leyes del nuestro quaderno de alcaualas, les condenan en muchas de las dichas penas e achaques ynjustamente e se les fasen otros muchos agrauios e synrasones. E asymismo, llamays e llevays ante vos las mugeres e fijas donsellas de los dichos nuevamente convertidos dis que vos quereys informar dellas sobre algunas cosas tocantes a las dichas rentas. A cabsa de lo qual se han ydo e van muchos vesinos de la dicha çibdad e su tierra de que han resçebido e resçiben mucho agrauio e danno $(\ldots)^{23}$

La situación en lo referente a los agravios recibidos por no hablar castellano no varió con los años, y queda patente en otra carta de 1507, en la que se especifica que el mayor daño lo sufren los "hombres de campo", lo que también es un dato muy interesante porque pone de manifiesto la diferencia existente entre el hablante rural y el urbano, entre el morisco que vive en la ciudad de Granada y el que vive en sus aldeas y villas:

Sepades que por parte del conçejo, justiçia, regidores, cavalleros, escuderos, vesinos e moradores de la dicha çibdad de [tachado: Gibraltar] Granada e sus alcarias, me fue fecha relaçion por su petiçion, dis que muchas veses los vesynos nuevamente convertidos a nuestra santa fee catolica de la dicha çibdad e sus alcarias son muy agrauiados e molestados en sus pleitos e negoçios a cabsa de ser enplazados por personas que no saben su lengua. Porque commo ellos por la mayor parte son onbres del canpo de que los enplazan en sus casas no les saben desyr para que dia ni ante qual juez ni a cuyo pedimiento son enplazados de lo qual dis que se sigue aquellos syn ser en culpa ni cargo se les echan rebeldias e se les fasen asentamientos e otras muchas costas e dannos e estorsyones de que no se pueden ni saben guardar ni remediar a cabsa de no entender en sus casas lo que los porteros que les enplazan dicen (...)los los mandase prouer mandando que los porteros e otras personas que los enplazasen fuesen personas que supiesen leer e escribir e fablar en aravigo e castellano para que en sus casas quando los enplasasen supiesen a mio pedimiento feran enplazados e para ente que juez e por cabsa dello no se les echasen rebeldias ni resçibiesen agrauios o commo la mi merçed fuese $(. . .)^{24}$

La reina doña Juana, en 1515, sigue dando testimonio de esta situación que se prolonga reiteradamente en el tiempo, en esta ocasión en escrito a la ciudad de Purchena:

23. AGS. Registro General del Sello. 1504, febrero, fol. 38.

24. AGS. Registro General del Sello. 1507, octubre, fol. 402. 
Sepades que por parte de la çibdad de Purchena e de los nuevamente convertidos della, me fue fecha relaçion por su petyçion diziendo que a cabsa quellos no saben la lengua castellana resçiben muchos agravios e estorsyones de los arrendadores e recabdadores que van a la dicha çibdad porque les mueven muchos pleitos e busos e otros achaques ynjustamente. E que commo no pueden poner procurador, se dexan cohechar de los dichos arrendadores e perder los dichos pleitos. Por ende, que me suplicava e pedia por merçed mandasen pudiesen poner cada vno en su cabsa propia o en otras relaciones vn procurador que syguiese los dichos pleitos porque por cabsa de no saber la dicha lengua no quedasen yndefensos y ellos perdiesen su justiçia $(\ldots)^{25}$

El que se mantuvieran permanentemente los agravios procedentes del desconocimiento del castellano por parte de los moriscos, además de por los beneficios económicos que pudiera desprenderse de ello al afectar a arrendadores y recaudadores, se entiende mucho mejor si se tienen en cuenta las creencias que el cristiano viejo ha consolidado sobre la naturaleza del árabe y sus hablantes, como veremos a continuación.

\section{LENGUA Y RELIGIÓN. ESTEREOTIPOS SOBRE USOS Y COSTUMBRES}

El árabe es la lengua del islam por excelencia ${ }^{26}$, lo que hace que el cristiano viejo que escucha hablar en árabe al morisco dude de la sinceridad de su conversión $^{27}$. Por otra parte, la tradición islámica ${ }^{28}$ les permite simular la conversión (taqiyya) en caso de que se vean forzados, siempre que en sus corazones sigan siendo musulmanes, el principio de darura, lo que hace bastante difícil descubrir si la conversión es o no verdadera.

El aspecto religioso alcanza también a las costumbres y a la forma de vivir; la sospecha y la desconfianza generalizadas serán constantes en esta época, de ahí que pronto llegue a identificarse hablar árabe con ser traidor a la fe cristiana y a la Corona. Su uso, aunque solo fuera superficial o afectase solamente a las grafías, era motivo suficiente para la intervención de la Inquisición o Santo Oficio ${ }^{29}$.

La lengua estaba en la esencia de la identidad cultural y religiosa de los moriscos. La imbricación entre lengua, cultura, y religión era tan intensa para el cristiano viejo que muchas de las medidas más importantes para la asimilación de esta comunidad tuvieron como objetivo muy destacado la prohibición del árabe.

Los estereotipos se proyectan no solo sobre la lengua, sino también, como antes decíamos, sobre todas aquellas costumbres y hábitos tradicionales -y religiosos- que acompañaban al morisco y que, desde la perspectiva del cristiano

25. AGS. Registro General del Sello. 1515, diciembre, fol. 531.

26. Liman 2002, p. 68.

27. Sobre este tema véase Abad Merino 2017b. Acerca de los conflictos más eruditos sobre la forma y manera de la posible conversión, véase Kimmel 2020.

28. https://es.wikipedia.org/wiki/Taqiyya.

29. Bernabé Pons 2009, p. 107. 
viejo, ocultaban traición y falsa conversión. Estos estereotipos podían ir desde la vestimenta $^{30}$ hasta la comida, la música ${ }^{31}$, los baños... tradiciones y hábitos culturales hacia los que se manifestaba una actitud completamente negativa. A través de los textos tenemos la oportunidad de conocer los prejuicios y los estereotipos más difundidos, pues ambos se encuentran en la base de las actitudes lingüísticas. Blas Arroyo señala que "los estereotipos se construyen a través de prejuicios que, a su vez, se retroalimentan en el desarrollo de las interacciones comunicativas, las cuales generan nuevos prejuicios que ayudan a consolidar los ya existentes" 32 .

Las creencias estereotípicas son representaciones mentales que se distinguen por los siguientes rasgos ${ }^{33}$ :

a. Son categorías que se sobregeneralizan o se sobresimplifican.

b. Son valorativas emocionalmente.

c. Se caracterizan por su persistencia y rigidez.

Forman parte del conocimiento común de una cultura. Los estereotipos acentúan una serie de aspectos, atribuidos con razón o sin ella, que la mayoría de las veces contienen una valoración positiva o negativa.

En este sentido, un documento sin fechar ni firmar consultado en el Archivo General de Simancas ${ }^{34}$ constituye un valioso ejemplo de lo que exponemos, por su generalización y vehemencia sobre casi todos los aspectos comprometidos en ese universo cultural. Se pronunciaba sobre la ausencia del morisco en ceremonias religiosas y cofradías ${ }^{35}$, por ejemplo:

Al conoçido no son lo uno ni lo otro ni son catolicos ni aun cristianos, pues jamas los vemos asistir a alguno de los divinos ofiçios si no es a la misa en las fiestas. Y aun llamados y llevados por fuerça, no sea visto morisco que se meta en cofadria

30. Elemento muy llamativo, por su carácter de exposición pública, la indumentaria asume también un rasgo identitario. Weiditz nos dejó un excelente testimonio gráfico sobre los moriscos granadinos, reproducido hasta la saciedad. Desde la perspectiva institucional y con intenciones integradoras, o represoras, tanto da en ese momento, contamos con cédulas como la de 1511, donde la Corona instaba a "que de aquí adelante ninguno de los nuevamente convertidos del dicho reino, hombres e mujeres, grandes e pequeños, no puedan hacer ni hacerse ropa de vestir a la manera de los moros, sino por la forma que las traen los cristianos viejos". Gallego Burín y Gámir Sandoval 1996, p. 174. Los historiadores granadinos, en su obra, recogen más documentación sobre el particular para las décadas posteriores, $\mathrm{y}$ no solo para el antiguo territorio nazarí, hecho que nos da buena cuenta de que la medida tuvo escaso éxito. La prueba es que en fecha tan tardía como la de 1571, y para los moriscos expulsados del reino tras la guerra, el concejo receptor de Lorca acordó prohibir esas mismas vestimentas. Jiménez Alcázar 1992, p. 124. Esta cuestión, como tantas otras, ya fue abordada por Caro Baroja (1985, pp. 136 y ss.). Moreno Díaz del Campo (2015a) insiste en el papel esencial de la mujer en la transmisión de los aspectos materiales del hogar y la vestimenta para consolidar la identidad del grupo, y para el impacto de la indumentaria morisca sobre las oligarquías cristianoviejas, véase Irigoyen García (2019).

31. Garrido García 2016.

32. Blas Arroyo 2005, p. 326.

33. Ribas 2005, p. 116.

34. Memorial dirigido al rey. Sin emisor ni fecha. AGS. Estado, legajo 169, pieza 334.

35. Es muy sugerente el intento de constituir una cofradía casi en las vísperas de la expulsión por los moriscos "de los del reino de Granada” establecidos en Lorca desde 1571. Jiménez Alcázar 1992, pp. 127-128. Citado también por García Pedraza 2002, p. 345. 
del Sacramento si quiera o de las animas ni se halla quen (sic) su testamento ayan dejado ni mandado obras pias (...)

Lo mismo sucede con lo relativo a los alimentos, a la ausencia de tocino en las casas moriscas o a la inexistencia de imágenes de santos:

No se les hallaron armas, porque con el ruydo de la polbora temieron la visita y las escondieron. Ni tanpoco se les hallaron una imajen de nuestra Señora ni pila de agua vendita, ni otra senal de cristianos, ni aun torrezno. Halloseles munchas pasa y higo, manjar que usan ellos muncho quando hazen sus çahores y ravadanes comiendo dello munchas vezes de estrella a estrella. Muncho dinero, joyas de oro $y$ plata y perlas.

Todo lo que está relacionado con sus hábitos y forma de vida era motivo de censura y de desconfianza, incluso el hecho de que fuesen hábiles en los negocios y equilibrados en su vida cotidiana, lo que no deja de ser interesante porque una posible virtud es mostrada como todo un ardid contra los cristianos viejos:

Para poder conseguir estos sus dañados fines, muy mejor procuran ser munchos. Esto consiguen con que no van a la guerra; no se enbarcan para Yndias; no entran en religión ni se consumen en pendençias y quistiones. Son sobrios y tenplados en el comer, y por esto de muy sana y larga vida.

Para ser ricos, an tomado por medio quatro cosas que son dos munchos y dos pocos. El un muncho es ganar muncho. El otro muncho es ahorrar muncho. El un poco es travajar poco y el otro poco es gastar poco para ganar muncho, ques de donde les proçede el ahorrar muncho. Se an metido en todo jenero de tratos, y ser trajineros y mesoneros de los tratos les proviene el ganar muncho, y al muncho ganar, muncho ahorrar y de los tratos les proviene el travajar poco, y al poco travajo poco gasto.

Estos ejemplos son representativos de la actitud más extendida entre los cristianos viejos, y ponen de manifiesto la abundancia y consistencia de los prejuicios, que pueden definirse, en opinión de Ribas ${ }^{36}$, como estados mentales compuestos de actitudes hacia grupos sociales, normalmente negativas, que corresponden a creencias estereotípicas.

Como ha podido apreciarse hasta aquí, lo habitual es que todos los ejemplos ilustren la perspectiva cristiano-vieja, ya que apenas contamos con testimonios directos procedentes de la perspectiva musulmana. En ese sentido, cabe mencionar la Carta que se tomó a Daud en la costa de Adra, que aparece incluida en la Historia del rebelión, de Luis del Mármol ${ }^{37}$; esta carta no es ficción, puesto que existe la versión traducida por el "romanceador" morisco Alonso del Castillo ${ }^{38}$, en la que se transmite esa otra percepción de la situación:

36. Ribas 2005 , p. 117.

37. Mármol 2015, pp. 172-174.

38. Sobre el traductor Alonso del Castillo es obligada la referencia a Cabanelas Rodríguez (1991), aunque han sido publicadas por algunos autores cartas romanceadas por él con diferente 
¡O señores mios! Abeis de saber que los xpianos nos han mandado quitar la lengua del algarabia, e quien perdiere el algaravia perderá su ley, e que descubramos las caras vergonçosas, e que no nos saludemos, e la mas noble virtud es la salutaçion. E nos han abierto puertas para que entre nosotros aya mas males e peccados, e nos han acrecentado el tributo e la pena, e han intentado de mudar nuestro trage, e quitar nuestras usanças... ${ }^{39}$

En este panorama, un caso excepcional es el que supone el célebre memorial de Francisco Núñez Muley ${ }^{40}$, caballero morisco ilustrado que siempre presentó una lealtad incondicional a los soberanos españoles que fueron sucediéndose, Isabel y Fernando, Carlos V y Felipe $\mathrm{II}^{41}$. Se presentaba como portavoz de la comunidad porque representaba su memoria histórica y daba voz a los que normalmente no la tendrían. Núñez Muley era leal a la corona, pero también era fiel a sus raíces y no quería renunciar a esa doble condición.

La argumentación de Núñez Muley no era tibia, pues hacía un denodado esfuerzo por separar lo que pertenecía al plano religioso de lo que eran costumbres y forma de vida de la comunidad morisca, como una más de las variantes culturales regionales existentes en la España de la época, en un intento de modificar la percepción del cristiano viejo para que no se siguieran identificando las tradiciones propias de la zona y del grupo con el hecho de ser musulmán.

\section{SOBRE LA MUJER Y LA LENGUA}

Su ausencia en la documentación hace pensar en el papel secundario que las mujeres moriscas desempeñaban en la sociedad de la época, pero cuando el tema que se aborda es el de la influencia de la mujer en los hábitos lingüísticos de la comunidad, entonces la situación da un giro inesperado, porque la creencia más extendida era que ellas eran las que más influían en el mantenimiento del árabe por su talante más conservador en lo que a innovaciones lingüísticas se refería. Contamos con testimonios célebres y con alguno inédito que refrendan la importancia de su papel como transmisora de la lengua materna. Entre los más conocidos cabe mencionar el Discurso del Doctor Esteban, obispo de Orihuela, sobre los medios que pueden ser más a propósito para la conversión de los cristianos nuevos del Reyno de Valencia ${ }^{42}$, que, aunque no se desarrolle en Granada es perfectamente extrapolable, más aún si consideramos que a partir de 1570, tras la revuelta de las Alpujarras, la población autóctona se vio notablemente incrementada por el gran número de moriscos granadinos que migró a Valencia:

contenido, así como documentación diversa (Espinar Moreno y Quesada Gómez 1996-1997; Espinar 1997; Martín Quirantes 2001; Abad Merino 2011...).

39. Castillo 1852, p. 43. https://sirio.ua.es/libros/BFilosofia/memorial_III/ima0077.htm.

40. Recogido por Carrasco Manchado 2012, pp. 368-401.

41. Vincent 2015, p. 93.

42. Citado en Boronat 1992, pp. 638-656. 
53. La mayor difficultad que tiene este negocio es ser las muger estan obstinadas y tan aversas a nuestro lenguage y mas en tierras tan grandes y en lugares tan poblados como tiene este obispado, en los quales biven pocos christianos viejos, pero si por cada vez que hablan algaravia les pusiessen dos reales de pena y la executassen muy bien (despues de haverles dado algun termino para aprender nuestra lengua) creo que podría haver buenas esperanças de su aprovechamiento.

En la Real Provisión de Felipe II de 1566 también encontramos una referencia a la especial dificultad que las mujeres granadinas mostraban para aprender la lengua castellana:

Y que los más de ellos, especialmente mugeres y niños, no entendian nuestra lengua ni podían ser enseñados ni doctrinados en la santa fee católica y religión cristiana, y heran pocos los ministros que supiesen la dicha lengua por cuyo medio pudiesen oyr y entender la dicha doctrina cristiana ${ }^{43}$.

En el memorial dirigido al rey del que no conservamos ni remitente ni fecha concreta, ya aludido y procedente del Archivo General de Simancas ${ }^{44}$, encontramos, una vez más, una información muy valiosa sobre este aspecto, por cuanto en él se detallan las razones por las que, en opinión de su anónimo autor, la comunidad morisca no aprendía el castellano. Incluso se elaboraba una propuesta -bastante peculiar, eso sí- para que esta situación cambiase definitivamente. Para este desconocido hablante las madres moriscas eran las responsables de que sus hijos se mantuvieran en la lengua arábiga, por lo que, si los niños fueran criados por mujeres cristianas viejas, esa influencia se perdería, se interrumpiría el vínculo de la lengua materna y las nefastas consecuencias que, a juicio del autor, esto traía consigo:

si la mujer del uno, la del otro, el ermano, padre o pariente que a de entrar en casa les a de servir a sus malos tratos, si los tienen, porque las madres christianas viejas les enseñaran a sus hijos la dotrina romançe castellano y perderian el aravigo que les enseñan las madres moriscas.

Para el obispo Esteve, como veíamos en el ejemplo antes mencionado, en la obstinación de la mujer había de encontrarse la principal causa de que los cristianos nuevos no aprendieran castellano, y en este memorial también parece atribuirse al papel de las mujeres el escaso éxito de las medidas lingüísticas propugnadas, por lo que en él se proponía la separación de las mujeres solteras en edad de concebir y las niñas en el seno de cada comunidad, como solución para el abandono

43. Real provisión para que los moriscos del reino de Granada abandonasen la lengua árabe, hablada y escrita, en el plazo de tres años, imponiendo diversas penas a los contraventores. AGS, Registro General del Sello, 1566, noviembre, s. fol. Mármol 2015, en el apéndice documental del editor de la obra, Castillo Fernández, p. 736.

44. AGS. Estado, legajo 169, pieza 334. Véase nota 34. 
definitivo de la lengua arábiga por parte de los nuevos nacidos y los más pequeños, que habría de conducir, además, a la religión cristiana:

El quitarles las hijas que tienen y las mujeres solteras que aun son de vientre servira juntamente con yrselas quitando, en aviendo tres años a dos y medio de questos no sepan la lengua de sus padres ni se puedan casar con moriscos, de manera que no criandose estas niñas con sus madres no savran la lengua puniendolas entre christianos viejos criarse como cristianos viejos aprenderan nuestra lengua, nuestra dotrina y santa $\mathrm{fe}^{45}$.

No tenemos demasiados testimonios sobre mujeres o en los que hablen las mujeres $^{46}$, por lo que a nuestro juicio es conveniente destacar la importancia de los que aquí presentamos, que podrían ponerse en relación con algunos postulados de la sociolingüística actual sobre el comportamiento lingüístico femenino, que muestran a la mujer más sensible a las normas prestigiosas que los hombres. Y ese prestigio puede localizarse en el uso de las formas propias de la comunidad, como en este caso, o en el uso de formas nuevas.

\section{El DisCURSO LINGÜÍSTICO. ACTITUdeS HACIA LA LENGUA DEL OTRO}

Después de analizar diferentes testimonios que nos muestran algunas actitudes orientadas hacia el grupo étnico, entre las que incluíamos la conciencia de la diferenciación o los estereotipos más difundidos sobre tradiciones y costumbres, vamos a centrarnos ahora en las actitudes hacia la lengua de ese grupo, en lo que podríamos considerar la conciencia más estrictamente lingüística. Para ello tendremos en cuenta todos los testimonios que se refieran explícitamente a la lengua, bien porque muestran las distintas maneras de reproducir la lengua del morisco -independientemente de que se trate de un forma real o imaginada-, bien porque reproduzcan juicios o prejuicios sobre la lengua misma. En este apartado pretendemos recoger aquellos testimonios documentales que hablan sobre la lengua, pero no sobre su construcción, sus componentes o sus diferentes planos comunicativos; no nos referimos a la "conciencia metalingüística", sino a la "conciencia lingüística externa" "47; es decir, la conciencia de "no hablar como los otros", la que permite diferenciar grupos según la variedad lingüística que emplean, ya sea esta un sistema diferente o una forma distinta de hablar un mismo sistema lingüístico,

45. Ibid.

46. Para la comunidad morisca de Cuenca contamos con el trabajo de García-Arenal (1987) en el que se analizan distintas causas del Tribunal del Santo Oficio y en los testimonios que allí se reproducen podemos acceder a las voces de las mujeres que intervienen de un modo $u$ otro en las causas, que nos hablan de la desigual competencia lingüística en árabe de hombres y mujeres y de granadinos y naturales.

47. Ribas 2005, p. 114. 
la que construye identidades y permite al grupo incluir o excluir a los otros. Intervienen, pues, elementos ideológicos, sociales, culturales y afectivos.

Como decía Alvar" ${ }^{48}$, en uno de los trabajos clásicos sobre esta cuestión: “desde su conciencia personal cada hablante es un juez que puede dirimir pleitos. Y esto afecta de manera decisiva al futuro de las hablas que se cotejan".

\subsection{Formas de reproducir la lengua del morisco}

En trabajos anteriores ${ }^{49}$ se pudo comprobar que, dada la desigual competencia lingüística en castellano de las distintas comunidades moriscas en lugares como el reino de Granada o el reino de Valencia, donde mayoritariamente se desconocía el castellano, la labor de los intérpretes era fundamental. En su intervención estaba la clave para la intercomunicación de cristianos y mudéjares primero, y de cristianos viejos y cristianos nuevos después. Mencionamos esta cuestión ahora porque, sin duda, no hay mejor forma de reproducir el discurso del «otro» que, a través de la traducción, lo que nos permitiría incluir ejemplos de esas intervenciones tanto en el plano escrito -romanceadores-, como en el plano oral -lenguas o intérpretes-, pero no lo haremos por dos razones. La primera es porque la intervención del traductor es un tema que ya se ha analizado detenidamente con anterioridad ${ }^{50} \mathrm{y}$, sobre todo, porque en este momento queremos mostrar los ejemplos más directos de esas formas de reproducir el lenguaje del morisco; es decir, la manera en la que se enfrenta el hablante castellano al reto de trasladar desde su propia lengua la lengua del «otro». Otra cosa será el grado de fidelidad de esa adaptación, pues habría que considerar en el proceso lo que el morisco pronunciaba, lo que el oyente entendía y, por último, la forma en la que lo escribía, sin olvidar que la procedencia geográfica de ambos podía afectar notablemente a cada uno de los momentos que hemos señalado. No obstante, esto es algo que no perjudica en absoluto a nuestro propósito, pues no se trata de documentar la fidelidad al sistema lingüístico, sino la evidencia de la percepción de esa diversidad.

A veces se trata de la reproducción de palabras sueltas, que viene requerida normalmente porque se emplean para designar realidades nuevas o ajenas al mundo del cristiano viejo. En algunas ocasiones, además, los autores actuaban casi como si de lexicógrafos se tratara, y explicaban la equivalencia entre ambas lenguas. Tal es el caso de Núñez Muley:

(...) para que quemasen las albardas de los que caminaren antes de misa y prendiesen a personas que se hallaren en cantares o musicas moriscas o en leylas, ques velar de noche con la dicha música y cantares, y penávales $(. . .)^{51}$

48. Alvar López 1977, p. 95.

49. Abad Merino 2006, 2008, 2017a.

50. Abad Merino 2011.

51. Carrasco Manchado 2012, p. 373 
(...) porque en verdad que la zanbra y estrumentos della no es cosa en que se ofende a la santa fee católica, ni ques de moros e çelimonias ni retos tocante a la seta de moros. Antes, vuestra señoría sabrá que el buen moro no se hallava en estrumentos de zanbra ni en plazer con ella. Y si algunos alfaquís o alcaldes heran convidados alguna boda, çesábase de tañer la dicha zanbra y estrumentos della hasta que los dichos alfaquís saliesen de la dicha boda o plazer $(. . .)^{52}$.

(...) que en el tiempo de santo alçobispo don Hernando de Talavera, primer alçobispo que los Reyes Católicos probeyeron en esta çibdad, y en su tiempo avía alfaquís y mostís, y tenían salarios de su casa algunos delllos que le enformavan a su señoría de las cosas tocantes a la seta y contra la seta $(\ldots)^{53}$.

No se establece ninguna equivalencia con la voz "zambra", lo que hace pensar en su popularidad y la difusión del término entre todos, más cuando era costumbre en el periodo morisco que participasen en fiestas cristianas. Es algo similar a los términos aparecidos en el memorial anónimo dirigido al rey citado con anterioridad:

(...) Halloseles munchas pasa y higo, manjar que usan ellos muncho quando hazen sus çahores y ravadanes comiendo dello munchas vezes de estrella a estrella. Muncho dinero joyas de oro y plata y perlas $(\ldots)^{54}$.

Cuando se trata de impuestos o tributos es fundamental conocer el nombre y la equivalencia, pues la política fiscal asumirá el sistema previo establecido nazarín ${ }^{55}$, como el almagrán o el talbix. Por eso, en muchas ocasiones se preguntará sobre los términos a los testigos moriscos de los pleitos de límites, normalmente ancianos para que su testimonio estuviera fundado en su experiencia y en su memoria.

Otro ejemplo es el que constituyen las cartas de dote y arras moriscas, donde cada objeto del ajuar de la novia recibe su nombre exacto, sin traslaciones, señal de que era un vocabulario, si no conocido, al menos familiar en su zona: $a b d u l$, alçoríes, almalafa, algaxabra, çequeb, etc., aunque planteaba un serio problema a los notarios, que se enfrentaban al desafío de tener que escribir los términos que el tasador pronunciaba en árabe ${ }^{56}$. Son muchos los trabajos que han abordado esta cuestión, especialmente para el estudio de arabismos en español ${ }^{57}$, por lo que no lo trataremos aquí.

En otras ocasiones se reproducen frases completas en árabe y no solo palabras sueltas. No es fácil encontrar ejemplos abundantes de este fenómeno, pero en los textos que estamos manejando en esta oportunidad ${ }^{58}$ sí puede localizarse alguno.

52. Ibid., p. 385.

53. Ibid.

54. AGS. Estado, legajo 169, pieza 334.

55. Galán Sánchez 2016.

56. Albarracín Navarro 1997; Calderón Campos 2012.

57. Martínez Ruiz 1966; Albarracín Navarro 1995, 1997.

58. En otra ocasión (Abad Merino 2006) citamos los ejemplos que García-Arenal (1987) presentaba para ilustrar la situación lingüística de la comunidad morisca de Cuenca y los retomamos ahora 
Buena muestra de ello es lo que aparece en un pleito por la fortaleza de Xiquena y sus tierras, situada en las cercanías de las villas de Vélez Rubio y Vélez Blanco. El litigio se abrió entre la ciudad de Lorca y el marqués de Villena en $1492^{59}$, recién conquistada Granada y donde la frontera militar había desaparecido cuatro años atrás, durante la ofensiva de 1488:

(...) el dicho AluaroYañez de Buytrago, procurador susodicho, en nonbre del dicho señor marques y de las dichas sus villas de Xiquena e Tirieça, e presento por testigos a Ali Albacar e Abrahin Aliaçan e Ali Alducarin e Abrahin Morçel, moros, vezinos de la dicha villa de Veliz el Blanco, de los quales e cada vno dellos reçibio juramento en forma de derecho en su ley, de consentimiento de las dichas partes e del dicho señor juez, Ali Alcadeque, moro alfaqui de la dicha villa, el qual juramento les tomo e reçibio en su lengua araviga, diciendo asy, poniendo el moro de cara el medio dia, "belehiheledoylehidehehilehuhet», que quiere dezir, de aravigo en la lengua ladina de comun hablar «por aquel Dios, que no hay otro syno El", que diran verdad de todo lo que supiesen e les fuese preguntado sobre razon de lo que heran presentados por testigos; $y$ a la confesyon del dicho juramento dixo cada vno por sy, sy juro e Amen $(\ldots)^{60}$

También es interesante el caso que vuelve a ofrecernos en su memorial Núñez Muley, quien recordaba las misas del arzobispo Hernando de Talavera, en las que se instalaba la zambra en el coro con los clérigos:

(...) y en los tienpos que avían de tañer los órganos, porque no los avía, respondía la zanbra e estrumentos della. Y dezía: "Dominus bobyspon” (sic), dezía, "y barafiqun" 61 .

En este mismo apartado cabría incluir la reproducción a través del castellano de antropónimos y topónimos de origen árabe, pues cuando menos implica una reflexión por parte del notario, escribano o emisor en general, sobre cómo reproducir dichos términos, normalmente muy alejados de su sistema lingüístico nativo. Esta situación supone, en nuestra opinión, otra muestra de esa conciencia lingüística a la que estamos apelando. Tan solo pondremos algunos ejemplos de esta "prueba" a la que se veían sometidos los profesionales de la escritura cuyas plumas han traído hasta nosotros los testimonios que nos permiten analizar estas

porque se trata de la reproducción de rezos y oraciones en árabe, según la percepción del escribano del Tribunal del Santo Oficio en distintas causas, donde se muestra claramente el proceso al que nos estamos refiriendo. Así, sirva le caso de Beatriz Padilla (García-Arenal 1987, p. 53) cristiana nueva, a la que su ama enseñó algunas oraciones cuyo significado, según su testimonio, desconocía: “bizmeleyaragemenoraginanguaquevar".

59. La extensa pieza documental que es el pleito conservado, al menos el relativo a los primeros años del proceso, se encuentra depositada en el Archivo Histórico Municipal de Lorca. Monog. Pleito de Xiquena, transcrito, estudiado y editado por Veas Arteseros (2017).

60. Ibid., p. 260.

61. Carrasco Manchado 2012, p. 386. 
situaciones. En 1492, en el mencionado pleito por Xiquena, además del ejemplo citado, nos encontramos con este otro:

(...) E, luego, el dicho Gonçalo Martinez de Ribera señalo e mostro antel dicho señor Alcayde Ali Haleytar e a Çad Çelemy e Abrahin Morzel e a Hamete Xaybany e a Mahomad Adega, a los quales les requirio mande /fol. 47v/ yr a la dicha çibdad de Lorca, como requerido tiene.

El qual dicho señor Alcayde dixo que los moros que señala, o la mayor parte dellos, son tales y en tal hedad e disposyçion que si les mandase yr, en el camino se moririan, e que sy los mandase yr e muriesen sus altezas serian deseruidos, de los quales fallo que mas razonablemente podran yr Mahomad Adega e Çad Çelemy, a los quales mando que mañana, por todo el dia, parezcan en la dicha çibdad de Lorca a dezir lo que saben $(. . .)^{62}$

Queremos insistir en el hecho de que no hay mejor forma de ejercitar la conciencia lingüística sobre la diferencia entre lenguas y visiones de mundo que a través de este tipo de representaciones. Sirva como elocuente ejemplo el localizado en el pleito entre doña María de Luna y el marqués de los Vélez por los términos entre las villas de Orce y Vélez Blanco:

(...) Yten sy saben e etc que la dicha villa de Orçe, asy en tienpo de moros commo después aca que es de christianos ha partydo e parte sus terminos con la dicha villa de Velez el Blanco por los limites e mojones syguientes: el primero mojon en lo alto de la cumbre de la syerra, en el puerto del Chirivel, que en aravigo se dicen Fegetrabit, e de alli viene por su derechera a otro mojon que dizen la loma del Alfaguara, e de alli por su derechera a la huente del Agua [fol. 2r] Blanca que en aravigo dicen Almi Alabiad, donde veni[an] a bever los ganados de Orçe e Velez, como apartymiento de [ter]minos. E de alli a otro mojon que dizen el puerto del Saladar, que en aravigo dicen Fajal Molaylaha, don[de] acaban de partyr terminos Orçe e Velez e comyençan a partyr terminos Velez con Huesca ${ }^{63}$.

De todas formas, es una constante en este tipo de pleitos de finales del XV y primeros años del XVI sostenidos a lo largo de la geografía granadina, pues el proceso de asiento castellano, en todos los planos, derivó en que en el registro documental aparezcan estas alusiones en árabe y en castellano, sobre todo en los aspectos referidos a la toponimia.

\subsection{Reproducción literaria. Estereotipos literarios}

La lengua del morisco ha llegado a nosotros también de una forma un tanto más ficticia, pero muy popular a través del teatro de los Siglos de Oro. En esta época aparecerán una serie de comedias que parodian la forma de hablar de los moriscos, claro ejemplo de la conciencia lingüística de la época, pues solo si el

62. Veas Arteseros 2017, p. 238.

63. AGS. Consejo Real, legajo 54, f. 2v. 
público y los autores compartían las mismas ideas podía explicarse el éxito de estas obras. Así se pueden apreciar las ideas comunes compartidas por la sociedad del momento y los prejuicios, que facilitan el aspecto cómico y burlesco de esa particular representación paródica y exagerada, cuando no inventada, de la lengua de los moriscos. No pretendemos ser exhaustivos en este tema, tan solo queremos mencionarlo para que la imagen de la recreación lingüística quede plasmada desde todos sus ángulos.

La figura del morisco aparecerá también en los romances, pero el aspecto lingüístico al que estamos aludiendo se desarrolla específicamente en las comedias y en algunas otras composiciones de carácter burlesco.

La justificación de esta identidad de criterio entre público y autores a la que nos referimos la encuentra Ferós ${ }^{64}$ en que antes del decreto de expulsión de 1609 la opinión pública estaba dividida o, cuando menos, mostraba diferencias en torno al "problema morisco" o a los moriscos en general. Mientras que unos creían que los moriscos eran inmunes al cambio y sus condiciones naturales hacían imposible su asimilación y lealtad a la fe cristiana y a la Corona, otros en cambio pensaban que sí era posible su integración en la sociedad católica, pues si se aferraban a sus señas culturales era por el rechazo social que padecían y la tibieza o desidia de las autoridades. Pero ese debate, esa diversidad de opiniones desapareció tras la firma del decreto por Felipe III. A partir de ese momento el discurso oficial y la opinión pública se hicieron una y esto afectó a todos los géneros literarios durante el siglo XVII.

La literatura se hace eco de la evolución de las ideas en la sociedad. Este espíritu era el común en el panorama literario español de la época, que llega incluso a atacar a la comunidad morisca, en un proceso de animalización que se lleva a cabo mediante el lenguaje, a través de adjetivos y de imágenes procedentes del mundo animal para conseguir de esta forma deshumanizar al grupo. El medio escrito se llena de comparaciones con alimañas, reptiles y fieras ${ }^{65}$, clara expresión iconográfica peyorativa por la significación que estos animales tenían para aquellas gentes, y que aún hoy permanecen.

No siempre fue así, puesto que los romances de frontera tradicionales y en los romances nuevos de moros la imagen no es negativa, sino que transmiten una visión estilizada y caballeresca de la sociedad mora ${ }^{66}$. En las comedias también hubo una evolución notable, puesto que el estereotipo negativo se desarrolla progresivamente, desde el teatro prelopesco, aunque alcanza su mayor desarrollo en las obras del "fénix de los ingenios".

Durante el reinado de Felipe II los moriscos son considerados como una amenaza, y este sentimiento negativo se verá reflejado en la literatura, especialmente en las comedias auriseculares, en las que se ridiculiza al morisco hasta reducirlo a un "fantoche sin importancia" 67 ; se proyecta una imagen de marginado, de

64. Ferós 2013, p. 68

65. Perceval 1992; Belloni 2015.

66. Carrasco Urgoiti 1982, p. 52.

67. Belloni 2012a, p. 41. 
rechazado, y nunca desempeña un papel principal. Así se construyó poco a poco el gracioso morisco, que se identificará sobre todo por su lenguaje especial; se trata de una jerga paródica con efecto cómico, única variedad que se muestra en las tablas cuando hablan los moriscos ${ }^{68}$ y que es el aspecto que ahora nos interesa. La comicidad se consigue por medio de los elementos identitarios más evidentes para el cristiano viejo: el nombre propio en árabe, la conversión al cristianismo, las referencias al vino y a tocino y, por supuesto, el uso de la jerga morisca. Este último aspecto es el que destaca sobre todos los demás por su enorme poder identificador.

Hay que tener siempre presente que se trata de un recurso cómico, muy popular y celebrado por el público, por lo que hay que proceder con cautela en lo referente a la base lingüística auténtica que puede tener, ya que se exageran los rasgos hasta la parodia. Somos conscientes en todo momento de que no se trata de un traslado riguroso de la variedad lingüística, aunque esta variedad literaria se basa en algunos rasgos del habla verdadera que potencia el efecto cómico, pero Lope no tenía intención de reproducir con exactitud la forma de hablar de este grupo ${ }^{69}$. Se trata de lo que conocemos como "hablas de minorías étnicas", categoría diferenciada de los "lenguajes especiales" por Salvador Plans ${ }^{70}$ y Carmona Tierno ${ }^{71}$, así como por Ariza ${ }^{72}$, que critica el concepto de "minoría" aplicado a rústicos o vizcaínos. Aunque cuando en una obra aparecen distintos personajes de una misma etnia, como en el caso de los moriscos, también se diferencian lingüísticamente, pues el protagonista-héroe utiliza un castellano literario impecable, mientras que la jerga cómica es el rasgo distintivo del criado gracioso u otro personaje secundario ${ }^{73}$.

En la definición que Carmona Tierno ${ }^{74}$ nos ofrece acerca de este tipo de hablas quedan recogidos los principales rasgos que las caracterizan de manera muy ilustrativa:

Las hablas de minorías pretenden representar la manera peculiar (y defectuosa) de hablar de determinados personajes pertenecientes a un grupo étnico, como los moriscos, los negros o los gitanos, o a uno sociocultural, como por ejemplo los pastores o los rústicos. Si nos centramos en las hablas de minorías étnicas, podríamos diferenciar dos clases: un español defectuoso, plagado de rasgos pertenecientes a la lengua materna del personaje; o lo contrario, un discurso supuestamente escrito (o mejor, dicho) en otra lengua aunque en realidad se trata de una jerigonza inventada en que lo extranjero es solo aparente, pues se compone de palabras españolas deformadas por los clichés lingüísticos de la lengua imitada o por voces muy conocidas de ellas, aunque dispuestas sin sentido.

68. Case 1982 .

69. Case 1981, p. 789; Belloni 2012b, p. 106.

70. Salvador Plans 2004, pp. 771-772.

71. Carmona Tierno 2013.

72. Ariza 1992, p. 51.

73. Camus Bergareche 1994, pp. 94-95. Para el tema étnico del morisco en la literatura pastoril, véase Irigoyen García 2013.

74. Carmona Tierno 2013, pp. 335-336. 
Como ya hemos dicho, no se trata de una imitación realista y rigurosa de la variedad específica de este grupo, sino de una deformación artificiosa como recurso cómico. Muchos rasgos serán arbitrarios, por lo que encontraremos algunos que imitan con más o menos fortuna una característica real, pero también otros que se alejan completamente de esa veracidad.

Parodias y bufonadas no reflejan la variedad auténtica empleada por el morisco, si bien muestran la imagen que el público reconocía a través de la interpretación de los autores. Aunque llegados a este punto no hay que olvidar lo que repetimos con insistencia desde el principio del estudio: no se puede hablar de "moriscos" como si no hubiera numerosas e importantes distinciones internas en general, y por lo que se refiere más específicamente a los aspectos lingüísticos en particular. Se hace difícil pensar que no habría diferencias bastante abultadas entre las diversas comunidades a la hora de hablar en castellano que, con toda probabilidad, no se verían recogidas en la literatura, poco interesada en plasmar estos matices y mucho más en captar la atención del público. Hay una distinción que no sabemos hasta qué punto pudo ser tenida en cuenta por autores como Lope o Quevedo -quien junto a Cervantes también utiliza el recurso-, pero que se convierte en fundamental, que es la que existe entre el morisco granadino y el morisco antiguo. Dadson ${ }^{75}$ considera que la gente de los pueblos conocía muy bien la diferencia, pero que, quizás, la de las grandes ciudades, al no estar en contacto con los distintos grupos, no la entendiesen tanto y entre estas gentes habría que situar a cristianos viejos como los grandes autores citados. Así, surge otra interrogación: ¿qué representa el habla de los moriscos graciosos de las comedias?, ¿es la supuesta pronunciación castellana del morisco granadino (urbano, por más señas, añadimos nosotros), que mantiene rasgos del árabe, o pretende ser la pronunciación del morisco antiguo que había dejado de hablar en árabe hacía varias generaciones?

Los documentos nos ofrecen un panorama distinto, pues cuando los moriscos hablan en ellos, si es que lo hacen, lo normal es que se expresen por boca de otro en la mayoría de las ocasiones, al desconocer el castellano si se trata de moriscos rurales granadinos o valencianos, ya que el ámbito urbano ofrece unos datos muy diferentes ${ }^{76}$. Solo un grupo social más elitista estará en condiciones de expresarse con claridad y escribir sus propios textos.

\section{CONCLUSIONES}

Los testimonios analizados nos han acercado a la situación real del momento, con la confirmación de que el panorama lingüístico se había convertido en un tema omnipresente en los más diversos ámbitos y entre todos los sectores sociales. Hemos podido conocer las actitudes y las creencias de unas comunidades a través de los testimonios verbalizados en el discurso lingüístico documental, pero

75. Dadson 2007, p. 275.

76. García Pedraza 2002. 
hay que destacar que no se trata del discurso oficial, sino que su valor reside en el hecho de que reflejan la opinión y la concepción global más difundida: son la evidencia de la percepción social del hecho, de la clara conciencia lingüística de una época.

La documentación es escurridiza y hemos de buscar rasgos en depósitos variados, ya que no existe un corpus definido, básicamente porque lo único que sí estuvo claro fue el objetivo de asimilación por parte castellana, hecho que no tuvo su correspondencia con ninguna institución que generase documentos específicos sobre la forma de obrar. Son pinceladas sueltas, que hacen a la vez más sugerente el tema propuesto de estudio por cuanto no se pretende "disimular": era evidente el deseo de conversión y asimilación a cualquier precio y por diferentes canales. Precisamente esa aparente política errática es la que hace que haya que buscar restos documentales en cartas, cédulas y expedientes varios, aunque los de mayor calidad son los pleitos ${ }^{77}$, sin duda alguna, allí donde el testigo morisco ${ }^{78}$ era imprescindible. Su testimonio, el papel decisivo del intérprete, el del escribano... se configuran como elementos claves en la comunicación, fuentes directas para confrontar el proceso del conflicto lingüístico nunca cerrado.

La realidad lingüística era la plasmación y reflejo del contexto generado tras las capitulaciones granadinas, pues la presión política, institucional y social con el grupo mudéjar desembocó en la rebelión de finales del siglo XV y la inmediata Conversión general, que dio paso al decreto de expulsión de 1502. La aparición del fenómeno "morisco" en el reino de Granada y en el conjunto de la Corona castellana, así como la concentración en determinados lugares del reino de Murcia o La Mancha ${ }^{79}$, complicó aún más la situación, por cuanto el teórico cambio de fe no solo se debía constatar en actos religiosos, sino en su idiosincrasia general. El objetivo de las autoridades castellanas fue, sin duda alguna, romper esas señas de identidad del grupo morisco con el fin de asimilarlo al conjunto general de la sociedad, y ninguna clave es más identitaria que la lengua. El hecho de que se asimile lengua y religión, como era el caso, hizo que las respuestas de unos y otros navegasen en un proceloso mar de desconfianza mutua, y las posturas apriorísticas se esbozaron desde un principio como un sentimiento general.

Si la "no asimilación" religiosa iba aparejada de la lingüística y de costumbres en general, sobre todo en las zonas más apartadas de los grandes núcleos urbanos, la decisión estuvo clara en determinados lugares donde en las vísperas de la rebelión la única persona que usaba el castellano era el cura.

Esa conciencia lingüística traspasaba pues, el simple hecho lingüístico, para convertirse en una identificación étnico-religiosa muy definida, además con el agravante del concepto "odio" entre ambas comunidades. El fenómeno monfí o de los cautiverios en la costa, además de una cruenta guerra, hizo que el enfrentamiento de 1568 a 1571 tampoco cerrase las heridas, y los prototipos del morisco como "vecino de segunda clase" los podamos observar en los diferentes géneros

77. Buena muestra de lo dicho en Peinado Santaella 2019.

78. Abad Merino y Jiménez Alcázar 2001.

79. Moreno Díaz del Campo 2009, 2015a. 
literarios donde tuvieron cabida, aumentado el fenómeno a raíz de su dispersión por tierras castellanas tras el final del conflicto.

La lengua se erigió como un referente no solo de identidad, sino también de identificación, pues se trató de un elemento que definía un contexto histórico. El idioma de sospecha y desconfianza, desde la perspectiva del cristiano viejo, tanto a título individual como institucional de los diferentes poderes castellanos, laicos y eclesiásticos, asume una importancia capital en todo el proceso de consolidación para unos y para otros. El hecho de que aludamos al fenómeno de alteridad al aludir a esta tragedia, como magistralmente la definieron Domínguez Ortiz y Vincent, es reflejo de lo dicho. Entenderse o no casi era lo de menos, pues en ese sentido, la lengua dejaba de tener la lógica del emisor y receptor para convertirse en un sustrato ideológico, identitario y religioso. Por ello, es un tema que aún admite mucha más profundidad y que abre caminos que condicionarán futuros hallazgos documentales en los ingentes fondos que aún quedan por descubrir.

\section{BIBLIOGRAFÍA}

Abad Merino, Mercedes (2006), "Intérpretes latentes y patentes en el periodo morisco (1501-1568). Del medio oral al medio escrito", Miscelánea Medieval Murciana, 29-30, pp. 9-26.

Abad Merino, Mercedes (2008), "El intérprete morisco. Aproximación a la historia de la traducción cotidiana en España en el ocaso de la Edad Media", Hermeneus, 10, pp. 23-53.

Abad Merino, Mercedes (2011), "La traducción de cartas árabes en un pleito granadino del siglo XVI. El fenómeno del romanceado como acto judicial: Juan Rodríguez y Alonso del Castillo ante un mismo documento", Al-Qantara, XXXII, pp. 481-518.

Abad Merino, Mercedes (2017a), "Mediación cultural y mediación lingüística en la frontera de Granada", Medievalismo, 27, pp. 113-43.

Abad Merino, Mercedes (2017b), "Moriscos y algarabía en la Corona de Castilla (s. XVI). La lengua como identidad de un grupo", Intus-legere. Historia, 11-2, pp. $35-60$.

Abad Merino, Mercedes y Jiménez Alcázar, Juan Francisco (2001), “Item si sabe...: el testigo morisco en los pleitos civiles castellanos", en M.J. Rubiera (ed.), Carlos I y el Islam, Alicante, pp. 27-38.

Albarracín Navarro, Joaquina (1995), "Una carta morisca de dote y arras. Granada (1540) y Juan Martínez Ruiz”, Sharq Al-Andalus, 12, pp. 263-276.

Albarracín Navarro, Joaquina (1997), "Nueve cartas moriscas de dote y arras de Vera (Almería) (1548-1551)", en P. Segura (coord.), Actas del Congreso la Frontera Oriental Nazarí como Sujeto Histórico (S. XIII- XVI): Lorca-Vera. Almería, pp. 517-529.

Alvar López, Manuel (1977), Comunicación y lenguaje, Madrid. 
Appel, René y Muysken, Pieter (1996), Bilingüismo y contacto de lenguas, Barcelona.

Ariza Viguera, Manuel (1992), "La lengua de las minorías en el Siglo de Oro", en M. Ariza (ed.), Problemas y métodos en el análisis de textos. In memoriam Antonio Aranda, Sevilla, pp. 49-69.

Belloni, Benedetta (2012a), "La evolución de la figura del morisco en el teatro español del siglo de Oro”, en C. Mata Induráin y A. J. Sáez (eds.), 'Scripta manent'. Actas del I Congreso Internacional Jóvenes investigadores Siglo de Oro, Pamplona, pp. 35-46.

Belloni, Benedetta (2012b), "«Que es gente que come arroz, pasas, higos y alcuzcuz»: la construcción de la imagen estereotipada del morisco en nueve comedias de Lope de Vega", Anuario Lope de Vega. Texto, literatura, cultura, XVIII, pp. 80-113.

Belloni, Benedetta (2015). "«Serpientes, alacranes y venenosas sabandijas»: la representación animalizada de los moriscos en la literatura apologética de la expulsión", en G. Cordone y M. Kunz, (eds.), Ficciones animales y animales de ficción en las literaturas hispánicas, Zúrich, pp. 89- 100.

Bernabé Pons, Luis F. (2009), “«Por la lengua se conoce la nación». Los moriscos y sus idiomas”, Alborayque: Revista de la biblioteca de Extremadura, 3, pp. 107-125.

Blas Arroyo, José Luis (2005), Sociolingüística del español. Desarrollos y perspectivas en el estudio de la lengua española en contexto social, Madrid.

Boronat y Barrachina, Pascual (1992), Los moriscos españoles y su expulsión, Granada, [1 ${ }^{\mathrm{a}}$ edición, Valencia 1901].

Cabanelas Rodríguez, Darío (1991), El morisco granadino Alonso del Castillo, Granada.

Calderón Campos, Miguel (2012), "Particularidades léxicas de las cartas de dote de los moriscos granadinos (1509-1513)", Cuadernos del Instituto de Historia de la Lengua, 7, pp. 61-88.

Caravedo Barrios, Rocío (2013), "La valoración como modelo de percepción y de significación", en A. Narbona Jiménez (ed.), Conciencia y valoración del habla andaluza, Sevilla, pp. 45-72.

Camus Bergareche, Bruno (1994), "Personajes orientales en el teatro clásico español: aspectos lingüísticos”, en F.B. Pedraza y R. Gonzáles Cañal (eds.), Los imperios orientales en el teatro del Siglo de Oro. Actas de las XVI Jornadas de teatro clásico de Almagro, Almagro, pp. 93-103.

Carmona Tierno, Juan Manuel (2013), "Las hablas de minorías en el teatro del Siglo de Oro: recursos de comicidad”, Teatro de palabras, 7, pp. 335-355.

Caro Baroja, Julio (1985), Los moriscos del reino de Granada, Madrid [1 ${ }^{\mathrm{a}}$ ed. 1957].

Carrasco Manchado, Ana Isabel (2012), De la convivencia a la exclusión. Imágenes legislativas de mudéjares y moriscos. Siglos XIII-XVII, Madrid. Incluye: Núñez Muley, Francisco (1567), Memoria para el presidente de la Chancillería de Granada sobre las cosas que hay en contra de la pragmatica que agora 
se pregona, para que sea informado de la verdad y favorezca a los naturales deste Reino ante su magestad, por Francisco Núñez Muley. Mss. 6176, fol. 333r [Mss. Micro 6941], pp. 368-401.

Carrasco Urgoiti, Ma Soledad (1982), "Notas sobre el romance morisco y la comedia de Lope de Vega", Revista de Filología española, 62, 1/2, pp. 51-76.

Case, Thomas E. (1981), "El morisco gracioso en el teatro de Lope", en M. Criado de Val (ed.), Lope de Vega y los orígenes del teatro español: Actas del I Congreso Internacional sobre Lope de Vega, Madrid, pp. 785-790.

Case, Thomas E. (1982), "The significance of Morisco Speech in Lope's Plays", Hispania, 65, 4, pp. 594-600.

Castillo, Alonso del (1852), Sumario e recopilación de todo lo romançado por mí el licenciado Alonso del Castillo, romançador del Santo Officio..., Memorial Histórico Español, vol. III, Madrid.

Dadson, Trevor J. (2007), Los moriscos de Villarrubia de los Ojos (siglos XV-XVIII). Historia de una minoría asimilada, expulsada y reintegrada, Madrid.

Espinar Moreno, Manuel (1997), "Escrituras árabes inéditas del siglo XV romanceadas por Alonso del Castillo", Miscelánea de Estudios Árabes y Hebraicos, 46, pp. 29-48.

Espinar Moreno, Manuel y Quesada Gómez, Ma Dolores (1996-1997), “Documentos arábigo-granadinos traducidos por Alonso del Castillo en 1565-1566", Revista del Centro de Estudios Históricos de Granada y su Reino, 10-11, pp. 229-256.

Fasold, Ralph (1996), La sociolingüística de la sociedad. Introducción a la Sociolingüística, Madrid.

Ferós, Antonio (2013), "Retóricas de la expulsión”, en M. García-Arenal y G. Wiegers (eds.), Los moriscos: expulsión y diáspora. Una perspectiva internacional. Valencia, pp. 67-101.

Galán Sánchez, Ángel (2016), "Identidad e intermediarios culturales. La lengua árabe y el fisco castellano tras la conquista del reino". Edad Media. Revista de Historia, vol. 17, pp. 109-132.

Gallego Burín, Antonio y Gámir Sandoval, Alfonso (1996), Los moriscos del reino de Granada según el sínodo de Guadix de 1554. Estudio preliminar de B. Vicent, Granada [1 ${ }^{\text {a }}$ ed. 1968].

García-Arenal, Mercedes (1987), Inquisición y moriscos. Los procesos del Tribunal de Cuenca. Madrid.

García Pedraza, Amalia (2002), Actitudes ante la muerte en la Granada del siglo XVI. Los moriscos que quisieron salvarse. I y II. Granada.

Garrett, Peter (2010), Attitudes to Language, Cambridge.

Garrido García, Carlos Javier (2016), "La aculturación musical de los moriscos del reino de Granada a través del ejemplo de los de la diócesis de Guadix", Boletín del Centro de Estudios Pedro Suárez: Estudios sobre las comarcas de Guadix, Baza y Huéscar, 29, pp. 109-124.

Irigoyen García, Javier (2013), The Spanish Arcadia: Sheep Herding, Pastoral Discourse, and Ethnicity in Early Modern Spain, Toronto. 
Irigoyen García, Javier (2019), «Moros vestidos como moros»: Indumentaria, distinción social y etnicidad en la España de los siblos XVI y XVII, Barcelona.

Jiménez Alcázar, Juan Francisco (1992), "Moriscos en Lorca. Del asentamiento a la expulsion (1571-1610)", Áreas, 14, pp. 117-140.

Jiménez Estrella, Antonio y Castillo Fernández, Javier (eds.) (2020), La rebelión de los moriscos del reino de Granada y la guerra en época de los Austrias. Estudios para un debate abierto, Granada.

Kimmel, Seth (2020), «Tener al lobo por las orejas». Polémicas sobre coerción y conversión hasta la expulsión de los moriscos, Madrid.

Liman,Taoufik (2002), "Lenguaje híbrido de los moriscos: entre el arraigo de su acervo cultural islámico y las vicisitudes del entorno", Anaquel de Estudios Árabes, 13, pp. 67-86.

López Morales, Humberto (1989), Sociolingüistica, Madrid.

Mármol Carvajal, Luis del (2015), Historia del rebelión y castigo de los moriscos del reino de Granada. Estudio, edición, notas e índices de Javier Castillo Fernández, Granada.

Martín Quirantes, Alberto (2001), "Nuevas aportaciones a la documentación de época mudéjar en la Vega de Granada: tres documentos romanceados por Alonso del Castillo", Revista del Centro de Estudios Históricos de Granada y su Reino, 15, pp. 289-307.

Martínez Ruiz, Juan (1966), "Siete cartas de arras del Archivo de la Alhambra (1546-1608)", Revista de Dialectología y tradiciones populares, 22, pp. 41-72.

Moreno Díaz del Campo, Francisco J. (2015a), "El hogar morisco: familia, transmisión patrimonial y cauce de asimilación”, Al-Kurras. Cuadernos de estudios mudéjares y moriscos, 1, pp. 97-119.

Moreno Díaz del Campo, Francisco J. (2015b), "El árabe de los moriscos castellanos. ¿Herramienta ritual o vehículo de cohesión socio-cultural?”, en J.A. Silva, M.F. Lopes de Barros y L. Mucznik (eds.), In the Iberian Peninsula. A History of Jews and Muslims (15th-17th centuries), Newcastle, pp. 164-185.

Moreno Fernández, Francisco (1998), Principios de sociolingüística y sociología del lenguaje, Barcelona.

Moreno Fernández, Francisco (2009), "Integración sociolingüística en contextos de inmigración: marco epistemológico para su estudio en España”. Lengua y migración / Language and Migration, 1/1, pp. 121-156.

Moreno Fernández, Francisco (2012), Sociolingüistica cognitiva. Proposiciones, escolios y debates, Madrid.

Moreno Fernández, Francisco (2015), "La percepción global de la similitud entre variedades de la lengua española”, en K.J.Kragh y J.Lindschouw (eds.), Les variations diasystématiques el leurs interdépendances dans les langues romanes, Estrasburgo, pp. 217-237.

Peinado Santaella, Rafael G. (2019), "La memoria alquilada de los moriscos: una breve aportación documental”, Chronica Nova, 2019, pp. 471-491. 
Perceval, José María (1992), “Animalitos del señor. Aproximación a una teoría de las animalizaciones propias y del otro, sea enemigo o siervo, en la España imperial (1550-1650)", Áreas, 14, pp. 173-184.

Perceval, José María (1997). Todos son uno. Arquetipos, xenofobia y racismo. La imagen del morisco en la monarquía española durante los siglos XVI y XVII, Almería.

Preston, Dennis (1993), “The uses of folk linguistics”, International Journal of Applied Linguistics,3-2, pp. 182-259.

Preston, Dennis (1999), Handbook of perceptual dialectology, Amsterdam.

Preston, Dennis (2003), "Language with an Attitude", en J.K. Chambers, P. Trudgill y N. Schilling-Estes (eds.), The handbook of Language Variation and Chande, Oxford, pp. 40-66.

Ribas, Rosa (2005), Testimonios de la conciencia lingüística en textos de viajeros alemanes a América en el siglo XVI, Kassel.

Salvador Plans, Antonio (2004), “Los lenguajes 'especiales' y de las minorías en el Siglo de Oro”, en R. Cano (ed.), Historia de la Lengua Española, Barcelona, pp. 771-797.

Veas Arteseros, Francisco de Asís (2017), El pleito de Xiquena. Estudio y edición, Cádiz.

Villanueva Zubizarreta, Olatz (2019), "Nacer mudéjar y morir morisco en Valladolid. Contratiempos al cumplimiento del decreto de 1502", Medievalismo, 29, pp. 411-430.

Vincent, Bernard (2015), El río morisco, Valencia.

Weinreich, Uriel (1974), Lenguas en contacto. Descubrimientos y problemas, Caracas $\left[1^{a}\right.$ ed. 1953$]$. 